\title{
HOLOCENTRUS TIGRINUS.
}

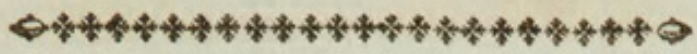

CHARACTER GENERICUS.

Opercula squamata, serrata, aculeata.

Bloch. ichth. 7. p. 4.5.

Thoracici.

CHARACTER SPECIFICUS, छc.

HOLOCENTRUS maculatus, pinna caudæ lunata.

$$
\text { Bloch. ichth. 7. p. 59. t. } 237 .
$$

Perea maxilla inferiore longiore, toto maculis et lineis transversis varia.

Seb. mus. 3. t. 27 . f. 15.

Prochilus capite producto, \&c.

Klein. misc. pisc. 5. t. 12,

A Percæ genere, cui certe admodum affine est, præcipue dignoscitur Holocentri genus, quod operculorum spinosa sit facies. Speciem elegantem descripsimus, maria Indica incolentem, eadem ut plurimum magnitudine qua Clupea vulgaris sive $\mathrm{Ha}$ rengus Linnæi. 


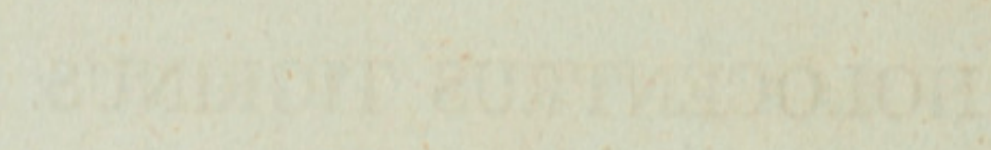





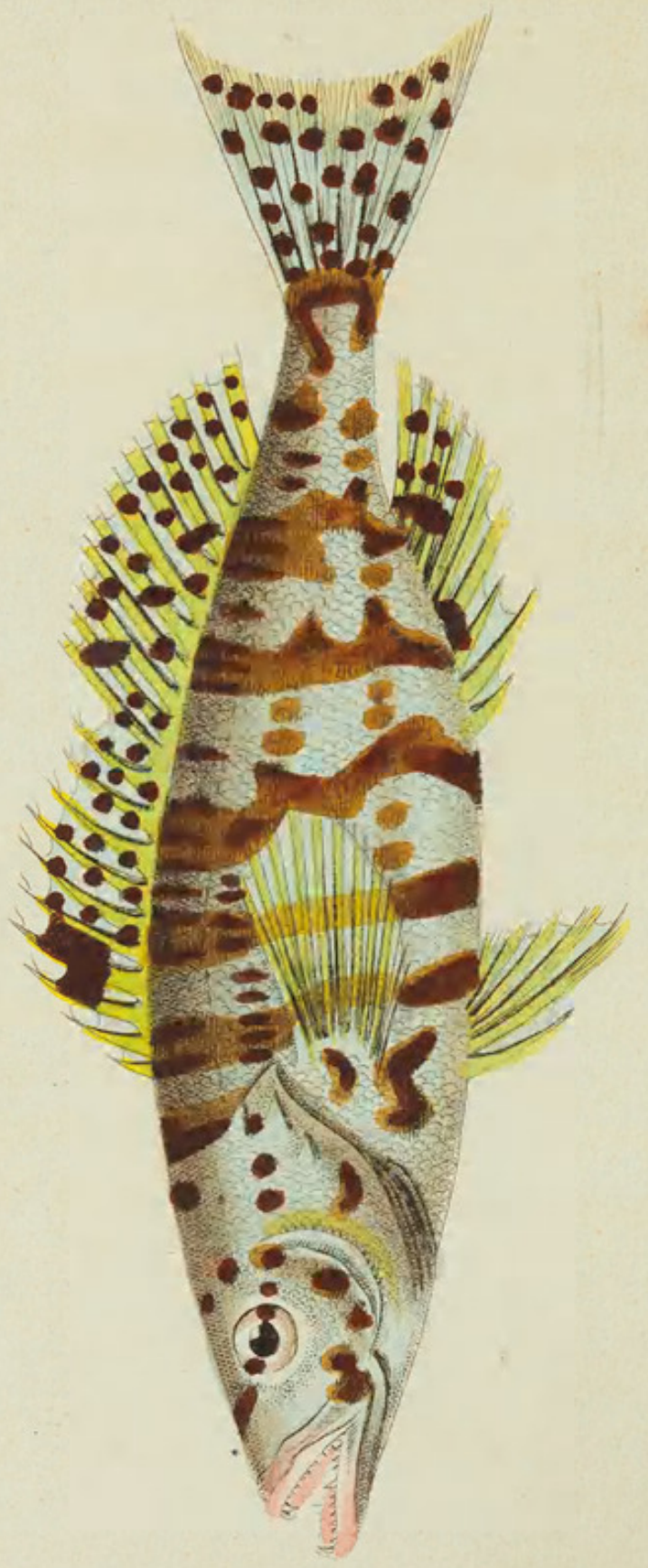

$\sum$ 
THE

\section{VARIEGATED HOLOCENTRUS.}

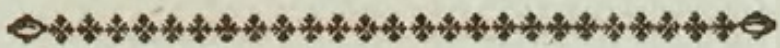

GENERIC CHARACTER.

Gill-Covers scaly, serrated, and spiny.

\section{SPECIFIC CHARACTER, §ंc.}

White HOLOCENTRUS with brown variegations.

\section{Tiger HOLOCENTRUS,}

La Marquille.

Renard Hist, Poiss. 1. t. 6. f. 45.

The genus Holocentrus is extremely allied to that of Perca, differing only in the spiny appearance of the opercula or gill-covers. The elegant species represented on the plate is a native of the Indian seas, and is generally of the size of a comman Herring. 


\section{$2 \mathrm{BHL}$ Biodiversity Heritage Library}

Shaw, George. 1801. "The Variegated Holocentrus, Holocentrus tigrinus [PI. 514]." The Naturalist's Miscellany 13(CXLV), https://doi.org/10.5962/p.310960.

View This Item Online: https://www.biodiversitylibrary.org/item/281546

DOI: https://doi.org/10.5962/p.310960

Permalink: https://www.biodiversitylibrary.org/partpdf/310960

\section{Holding Institution}

Museums Victoria

\section{Sponsored by}

Atlas of Living Australia

\section{Copyright \& Reuse}

Copyright Status: Public domain. The BHL considers that this work is no longer under copyright protection.

This document was created from content at the Biodiversity Heritage Library, the world's largest open access digital library for biodiversity literature and archives. Visit BHL at https://www.biodiversitylibrary.org. 